ЕКСПЕРИМЕНТАЛЬНА ТА КЛІНІЧНА ФАРМАКОЛОГІЯ

\title{
MODERN ASPECTS OF DEVELOPMENT AND TREATMENT OF RHINOSINUSITIS
}

\author{
S.V.Oleinik
}

National University of Pharmacy

Key words: chronic diseases; rhinosinusitis; therapy; drugs; homeopathic medicines

Rhinosinusitis is one of the most common chronic diseases. The studies in recent decades have shown that approximately $10 \%$ of rhinosinusitis have an endogenous nature. According to statistics, women more often suffer from rhinosinusitis than men, as well as people from the higher social strata of society. According to the literature, patients with rhinosinusitis are about one third of the total number of hospitalizations in ENT in-patient departments. Foci of inflammation in the paranasal sinuses can be a source of infectious sensitization of the respiratory tract and lungs, as well as the cause of severe intracranial complications. Therefore, the problem of the treatment of rhinosinusitis remains one of the most urgent and difficult in otorhinolaryngology. The empirical antibiotic therapy is the basic treatment of acute bacterial rhinosinusitis, as well as exacerbation of chronic rhinosinusitis. Drugs of the first choice in acute rhinosinusitis are amoxicillin, amoxicillin/clavulanate. Cephalosporins, e.g., cefuroxime axetil, are another way of treatment. Drugs, which are prescribed in the case of failure of the first course of antibiotics, are macrolides and fluoroquinolones of the III-IV generations such as levofloxacin and moxifloxacin. The use of traditional medicines has a positive therapeutic effect, but side effects of glucocorticoids and vasoconstrictors for topical application are associated with the risk of retinal vascular embolism and development blindness. Therefore, today the use of homeopathic complex drugs based on the components of the plant, animal and mineral origin is topical since they are as effective as allopathic drugs, do not exhibit undesirable side effects, drug intolerance and the effect of habituation, and do not cause allergic reactions.

Nowadays there is the increased progression of nasal phlogistic diseases, especially in chronical forms, it often leads to the loss of labour capacity, and if the intracranial complications are developed, it can result in patient's disability and death. According to the WHO data 235 million people suffer from asthma, 64 million have lungs chronic obstructions, while billions of people are diagnosed with allergic rhinitis and other chronic respiratory diseases $[4,5]$.

The nasal cavity and sinus are the highly organized structure with subtle and complicated regulation mechanisms possessing a lot of specific functions.

Rhinosinusitis is inflammation of the sinus and nasal cavity caused by congestion of secretion and aeration disorder. The starting point for development of rhinosinusitis is an acute respiratory viral infection [13].

According to the American Healthcare Bureau 14.7\% of the Americans suffer from rhinosinusites. According to the US Disease Statistics Center rhinosinusitis has become the most spread chronic disease in the country, exceeding the indicators of the diagnosis of arthritis and hypertension. Dependence of the disease on the sex of the patients, the place of residence and the social status has been also studied. According to the US statistics, women are suffering from rhinosinusitis more often than men, as well as people from the higher social strata of society $[9,11]$.

In addition, studies conducted in Russia have proven that patients with rhinosinusitis have significantly lower indices of pain sensitivity and social activity than patients with coronary heart disease and chronic obstructive pulmonary disease. In $26 \%$ of patients rhinosinusitis is accompanied by development or progression of mental depression [1].

When studying the structure of morbidity of the otolaryngology organs in Moscow city clinical hospital No.4 it has been found that the largest nosological group includes diseases of the nasal cavity and paranasal sinuses $(\sim 54 \%$, Fig.). The ear pathology $(25 \%)$ is the second, and diseases of the pharynx $(10 \%)$ are the third [1].

The analysis of the statistical data shows that there is a consistently high percentage of prevalence of diseases of the nasal cavity and paranasal sinuses. Due to that it is vital to develop the measures to improve the medical care of patients with these diseases $[1,12]$.

In recent years the incidence of rhinosinusitis has almost 3 times increased, while the number of hospitalized people has increased by $1.5-2 \%$. Thus, the problem of treatment of rhinosinusitis remains one of the most urgent and complex [4]. 


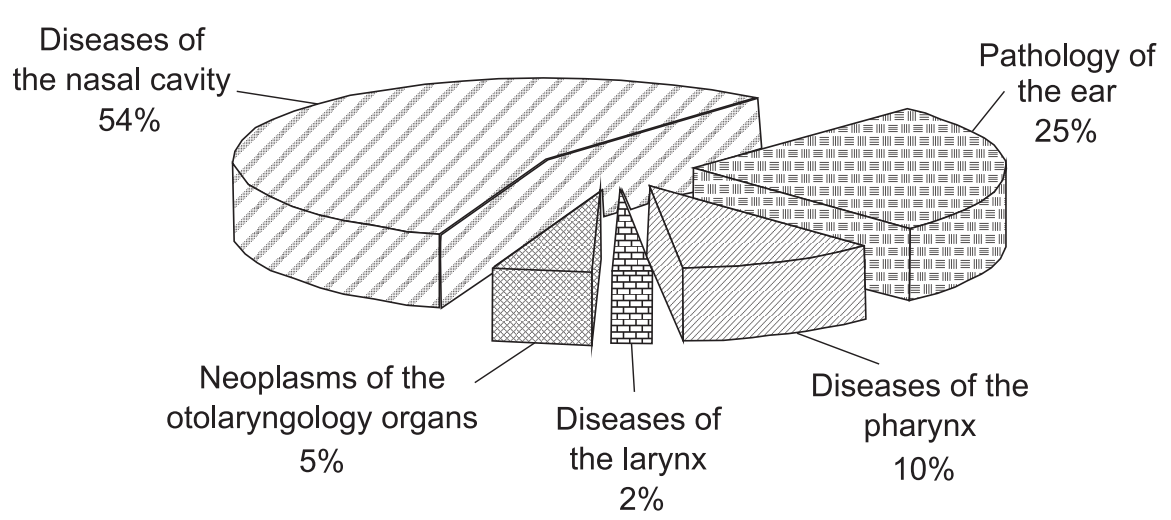

Fig. The structure of morbidity of the otolaryngology organs.

The main aim of treatment of rhinosinusitis is to reduce duration of the disease; prevent the intracranial complications; eradicate the pathogen. In that way the basic method of treatment of acute bacterial rhinosinusitis and exacerbation of chronic rhinosinusitis is an empiric antibacterial therapy (amoxicillin/clavulanate, etc.) [2].

In the USA the frequency of using antimicrobial agents reaches 80\%, in Europe - 72-92\% [13].

The disease ranks 5 th among diseases when antibiotics are prescribed: the USA spends approximately 6 billion $\$$ to buy antibiotics for treating rhinosinusitis [14].

According to the pharmacoepidemiological research conducted in Russia it has been found that amoxicillin is a drug of the first choice being prescribed to $18 \%$ of patients. In $13.5 \%$ of cases ciprophloxacin is prescribed, ampicillin - in $12 \%$ of cases, doxycyclin - in $7.7 \%$ of cases and stand for gentamicin - in 5.5\% of cases. Amoxicillin is prescribed only for $16.7 \%$ of patients, amoxicillin/clavulanate - only for $3.1 \%$ of patients $[7,9]$.

However, in practice, there are often situations when the choice of treatment of rhinosinusitis is complicated by intolerance to antibiotics.

Such vasoconstrictors as naphazoline, oxymetazoline, xylometazoline become essential in therapy of rhinosinusitis; they affect the nasal cavity tonus regulation. But the use of these medicines can cause edema in the nasal cavity, changes in histological structure of the mucosa, i.e. development of drug-induced rhinitis.

The therapy of acute rhinosinusitis also uses herbal medicines with the antiphlogistic and mucolytic effect (Erespal, Sinuforte, Sinupret). It is the combination of synergistic active substances that provides the complex secretolytic, anti-edema, bronchodilatatory, anti-inflammatory and immunostimulating effects when treating rhinosinusitis [2].

In 2012 based on the results of several randomized controlled clinical studies the updated European recommendations for treatment of rhinosinusitis (European position paper on rhinosinusitis and nasal polyps (EPOS)) were published. The document reflects the issues of determination, including the classification and epidemiology, contributing to the factors of development and treatment of rhinosinusitis. One of the new aspects of EPOS-2012 is the inclusion of recommendations for the treatment of some forms of rhinosinusitis with herbal drugs (recommendations A) [11].

Tab. 1 generalizes the recommendations on the therapy of acute rhinosinusitis in adults containing in the EPOS up-to-date edition (2012).

The herbal drugs possess many advantages compared to the synthetic ones, e.g. when using medicines from plants allergic reactions and unwanted effects develop less often [6].

Combining the methods of traditional medicine and homeopathy allows to achieve a relatively quick desired effect when treating many diseases. The efficiency, safety, the absence of side effects, economic availability make homeopathic medicines indispensable for use in children, pregnant women, elder people and patients with a tendency to allergic reactions [8].

The search of new medicines by studying the toxic and dynamic properties ("medicinal pathogenesis" ac-

Table 1

The recommendation level when treating acute rhinosinusitis (EPOS-2012)

\begin{tabular}{|l|c|l|}
\hline \multicolumn{1}{|c|}{ Therapy } & Recommendation level & \multicolumn{1}{c|}{ Indication } \\
\hline Antibiotics & A & In the case of acute bacterial rhinosinusitis \\
\hline Topical (intranasal) HCSs & A & In the case of allergic rhinosinusitis \\
\hline Saline nose washing & B & In the case of all rhinosinusitis forms \\
\hline Anti-histamines + decongestants & A & In the case of acute viral rhinosinusitis \\
\hline Probiotics & A & For prophylaxis of acute rhinosinusitis \\
\hline Phytodrugs, aspirin, paracetamol & A & In the case of acute viral rhinosinusitis \\
\hline Decongestants, mucolytics & D & Not used \\
\hline Zinc, vitamin C, Echinacea & C & Not used \\
\hline Steam inhalations & A & Not used (ineffective) \\
\hline
\end{tabular}


Complex homeopathic medicines used in the therapy of rhinosinusitis

\begin{tabular}{|l|l|l|l|}
\hline \multicolumn{1}{|c|}{ Name } & \multicolumn{1}{|c|}{ Manufacturer } & \multicolumn{1}{c|}{ Dosage form } & \multicolumn{1}{c|}{ Indications } \\
\hline Cinnabsin & $\begin{array}{l}\text { Deutsche Homeopathy- } \\
\text { Union DHU (Germany) }\end{array}$ & Homeopathic tablets & $\begin{array}{l}\text { Complex therapy of acute and chronic nasal } \\
\text { inflammations (sinusitis, frontal sinusitis) }\end{array}$ \\
\hline Rhinital & RHU (Germany) & Homeopathic tablets & $\begin{array}{l}\text { Allergic rhinitis as a part of complex } \\
\text { therapy }\end{array}$ \\
\hline Asinis & Heel (Germany) & $\begin{array}{l}\text { Homeopathic nasal } \\
\text { spray }\end{array}$ & $\begin{array}{l}\text { Rhinitis of different etiology, chronic } \\
\text { sinusitis }\end{array}$ \\
\hline Euphobium Compositum & Hichard Bittner (Austria) & $\begin{array}{l}\text { Homeopathic nasal } \\
\text { spray }\end{array}$ & $\begin{array}{l}\text { Rhinitis of different etiology, chronic } \\
\text { sinusitis, pharyngitis }\end{array}$ \\
\hline Delufen & EDAS (Russia) & Nasal drops & $\begin{array}{l}\text { Acute and chronic rhinitis (including } \\
\text { allergic one) }\end{array}$ \\
\hline Edas-131 & Walsh Pharma (USA) & Homeopathic tablets & $\begin{array}{l}\text { Allergic rhinitis as a part of complex } \\
\text { therapy }\end{array}$ \\
\hline Coryzalia & Boiron Lab (France) & Homeopathic tablets & $\begin{array}{l}\text { Rhinitis (edema and/or irritation of the } \\
\text { nasal mucosa, sneezing) }\end{array}$ \\
\hline
\end{tabular}

cording to Hannemann) of different organic and inorganic substances is constantly carried out. That is why new homeopathic medicines appear at the pharmaceutical market [10].

The given facts determine the relevance of developing new domestic homeopathic medicines, first of all, their complex forms. The complex homeopathic forms can be considered as the drugs of choice in cases when administration of allopathic medicines are particularly undesirable - during pregnancy, in allergies, among the little children, as well as in diseases of the liver and kidneys. The complex homeopathic medicines have become the essential assortment part in both homeopathic and conventional pharmacies. In the structure of the turnover of large wholesale firms the sale of homeopathic medicines is up to $5 \%[3,8]$.

The complex homeopathic medicines for prevention and treatment of rhinosinusitis registered in Ukraine are given in Tab. 2.

The assortment presented shows the insufficient quantity of complex homeopathic medicines for rhinosinusitis at the Ukrainian market. The German manufacturers offer 3 drugs for complex therapy of nasal diseases, the Austrian manufacturers -2 drugs, the Russian, US and French manufacturers -1 drug per a country for treating rhinitis of different etiology. Besides, there are no domestic medicines. Therefore, it proves the relevance of developing and creating new and effective homeopathic medicines in our country.

\section{CONCLUSIONS}

The pharmaceutical, medical and social significance of the problem of rhinosinusitis is conditioned by a high prevalence of this disease, a pronounced decrease in the quality of patients' life, the existence of resistant and recurrent forms.

The main method of drug treatment is antibacterial therapy. Usually the drug of choice for treatment of rhinosinusitis is amoxicillin or amoxicillin clavulanate. The traditional drugs often become ineffective and have different side effects causing complications of the disease.

The combination of antibacterial and homeopathic therapy allows to considerably improving the results of treatment of patients with this pathology. The assortment of complex homeopathic medicines for rhinosinusitis at the Ukrainian market is limited, and there are no domestic drugs.

The further studies on development of the composition and technology of a complex homeopathic medicine for use in practical otolaryngology, in particular for prevention and treatment of rhinosinusitis, are required.

\section{REFERENCES}

1. Бицаева A.B. // The Scientific \& Educational Bulletin "Health \& Educational Millennium". - 2012. - T. 14, №5. - P. 1-2.

2. Гилифанов Е.А., Иченко В.Б., Лепейко Б.А. и др. // Вестник оториноларингол. - 2011. - №6. - С. 100-102.

3. Гомеопатические лекарства (в помощь провизору) / Сост. А.Ф.Пиминов, Л.А.Печенежская, В.Г.Кириченко, В.Н.Хоменко. - Х., 2008. - 36 с.

4. Крюков А.И., Туровский А.Б., Талалайко Ю.В. // РМЖ. - 2010. - №7. - С. 435-438.

5. Лопатин А.С., Варвянская А.В. // Мед. совет. - 2014. - №3. - С. 24-26.

6. Махлаюк В.П. Лекарственные растения в народной медииине - М.: Высш. шк., 2007. - C. 451-452.

7. Панякина М.А., Овчинников А.Ю., Мирочниченко Н.А. // Фарматека. - 2013. - №4. - С. 69-73. 
8. Радичи Е.Ю. // Рус. мед. журн. - 2007. - T. 15, №1. - C. 1-5.

9. Chow A.W., Benninger M.S., Brook I. et al. // Clin. Infect. Dis. - 2012. - №54 (8). - P. $72-112$.

10. Ernst E. // Trends Pharmacol. Sci. - 2010. - Vol. 31. - P. 1.

11. Fokkens W., Lund V.J., Mullol J. et al. // Rhinol. - 2012. - Suppl. 23. - P. 1-298.

12. Jund R., Mondigler M., Steindl H. et al. // Rhinol. - 2012. - №50. - P. 417-426.

13. Wang D.Y., Wardani R.S., Singh K. et al. // Rhinol. - 2011. - №49 (3). - P. 264-271.

14. Williamson I.G., Rumsby K., Benge S. et al. // JAMA. - 2007. - Vol. 298. - P. 2487-2496.

\section{СУЧАСНІ АСПЕКТИ РОЗВИТКУ ТА ЛІКУВАННЯ РИНОСИНУСИТУ}

С.В.Олійник

Ключові слова: хронічні захворювання; риносинусит; терапія; лікарські препарати; гомеопатичні лікарські засоби

Риносинусит відноситься до числа найпоширеніших хронічних захворювань. Дослідження останнього десятиліття показали, що приблизно 10\% риносинуситів мають ендогенну природу. За статистикою на риносинусити частіше хворіють жінки, а також люди з вищих соціальних верств суспільства. За літературними даними хворі на риносинусити становлять близько 1/3 від загального числа госпіталізованих в ЛОР-стаціонари. Вогнища запалення в навколоносових пазухах можуть бути джерелом інфекційної сенсибілізації дихальних шляхів і легенів, а також причиною важких внутрішньочерепних ускладнень. Тому проблема лікування риносинуситів залишається дотепер однією з актуальних і складних в оториноларингології. Базисним методом лікування гострого бактеріального риносинуситу, а також загострення хронічного риносинуситу є емпірична антибактеріальна терапія. Препаратом першого вибору при гострому риносинуситі є амоксицилін, амоксицилін/клавуланат. Іншим варіантом лікування є цефралоспорини, наприклад, цефуроксиму аксетил. Засобами, які призначають у разі неефективності першого курсу антибіотикотерапії, є макроліди та фрторохінолони IIIIV поколінь: левофлоксацин, моксифлоксацин. Застосування традиційних лікарських засобів чинить позитивний терапевтичний ефект, проте побічні ефректи глюкокортикостероїдів і судинозвужувальних лікарських препаратів для місцевого застосування пов'язані з ризиком емболії судин сітківки та розвитку сліпоти. Тому сьогодні є актуальним застосування гомеопатичних комплексних препаратів на основі компонентів рослинного, тваринного та мінерального походження, оскільки вони за ефективністю не поступаються алопатичним препаратам, не проявляють небажаної побічної дії, ефректів непереносимості препаратів $i$ звикання та не викликають алергічних реакцій.

\section{СОВРЕМЕННЫЕ АСПЕКТЫ РАЗВИТИЯ И ЛЕЧЕНИЯ РИНОСИНУСИТА С.В.Олейник}

Ключевые слова: хронические заболевания; риносинусит; терапия; лекарственные препараты; гомеопатические лекарственные средства

Риносинусит относится к числу самых распространенных хронических заболеваний. Исследования последнего десятилетия показали, что примерно 10\% риносинуситов имеют эндогенную природу. По статистике риносинуситом чаще болеют женщины, а также люди из высших социальных слоев общества. По литературным данным больные риносинуситом составляют около 1/3 от общего числа госпитализированных в ЛОР-стационары. Очаги воспаления в околоносовых пазухах могут быть источником инфекционной сенсибилизации дыхательных путей и легких, а также причиной тяжелых внутричерепных осложнений. Поэтому проблема лечения риносинусита остается одной из актуальных и сложных в оториноларингологии. Базисным методом лечения острого бактериального риносинусита, а также обострения хронического риносинусита является эмпирическая антибактериальная терапия. Препаратом первого выбора при остром риносинусите являются амоксициллин, амоксициллин/клавуланат. Другим вариантом лечения являются цефралоспорины, например, цефуроксим аксетил. Средствами, которые назначают в случае неэфрфективности первого курса антибиотикотерапии, являются макролиды и фрторхинолоны III-IV поколений: левофрлоксацин, моксифрлоксацин. Применение традиционных лекарственных средств имеет положительный терапевтический эффрект, однако побочные эффректы глюкокортикостероидов и сосудосуживающих лекарственных препаратов для местного применения связаны с риском эмболии сосудов сетчатки и развития слепоты. Поэтому сегодня является актуальным применение гомеопатических комплексных препаратов на основе компонентов растительного, животного и минерального происхождения, поскольку они по эффективности не уступают аллопатическим препаратам, не проявляют нежелательных побочных действий, непереносимости препаратов и эфффекта привыкания и не вызывают аллергических реакций. 